\section{Ploidy Level, Karyotype, and Genome Size of Bletilla Species (Orchidaceae) From China}

\author{
Yan He, Lulu Yang, Yanjun Zhang, and Qiong Liang
}

Key Laboratory of Plant Germplasm Enhancement and Specialty Agriculture. Wuhan Botanical Garden, Chinese Academy of Sciences, Wuhan 430074, China

Additional index words. Bletilla, chromosome, karyotype, nuclear DNA content, ploidy level

Abstract. Bletilla is an Orchidaceae genus with high medical value, including detumescence, antibacterial, and hemostasis. In this study, detailed estimates of ploidy level, karyotype, and genome size were first obtained, and a comprehensive cytological analysis was carried out to better understand the evolution of the genus. The karyotypes of Bletilla were mainly composed of metacentric and submetacentric chromosomes with lengths ranging from 1.25 to $4.93 \mu \mathrm{m}$. There was moderate cytological variation in Bletilla (chromosome number $2 n=32$ to 76 ). Diploid with $2 n=34$ and $2 n=36$ was detected in Bletilla ochracea and Bletilla formosana, respectively, whereas diploid $(2 \mathrm{n}=32)$ was dominant in Bletilla striata, dysploidy $(2 \mathrm{n}=34,2 \mathrm{n}=36)$ and polyploid $(2 \mathrm{n}=48,51,64,76)$ variations were also observed. Three species had a relatively symmetric karyotype, and which of $B$. ochracea was more asymmetry. The genome size (1C-values) varied from $2.94 \mathrm{pg}$ (B. striata) to $3.33 \mathrm{pg}$ (B. ochracea), of which B. ochracea was significantly larger than the others $(P<0.05)$. A positive correlation $(P<0.01)$ between $1 \mathrm{C} x$ vs. haploid chromosome length (HCL) and asymmetry coefficient of karyotypes (AsK\%) was observed.

Bletilla Reichb.f. is a small genus with five species, including B. striata (Thunb.) Rchb.f., B. ochracea Schltr., B. formosana (Hayata) Schltr., Bletilla foliosa (King \& Pantl.) Tang \& F.T.Wang and Bletilla chartacea (King \& Pantl.) Tang \& F.T.Wang (http://www. theplantlist.org), primarily distributed in Asia from Myanmar, southern and eastern China, to Japan and Korea. China is its distribution center with four species, except for $B$. chartacea (Chen X. et al., 2009). Among the four species, B. striata is the main traditional medicinal resource recorded in the Shennong's Classic of Materia Medical and is also the only one recognized in the Chinese Pharmacopoeia (2020 edition). Its pharmacological values include detumescence, antibacterial, hemostasis, and antitumor properties, among others (Chen et al., 2020; Zhou et al., 2020). However, wild resources of Bletilla have sharply decreased due to the limited natural reproduction, increased utilization, and natural habitat destruction. Consequently, Bletilla has been included in the List of National Key

Received for publication 12 July 2021. Accepted for publication 2 Sept. 2021.

Published online 14 December 2021.

This research was funded by the National Natural Science Foundation of China (31771871), Biological Resources Program, Chinese Academy of Sciences (KFJ-BRP-007; KFJ-BRSN-2018-6-002). We acknowledge Jing Yang of Kunming Botanical Institute, Chinese Academy of Sciences for providing technical guidance.

Q.L. is the corresponding author. E-mail: qiongl@ wbgcas.cn.

This is an open access article distributed under the CC BY-NC-ND license (https://creativecommons. org/licenses/by-nc-nd/4.0/). information for species identification and diversity studies (Guerra, 2012; Jang and Weissschneeweiss, 2018). Furthermore, they also play a key role in establishing phylogenetic relationships between species and inferring evolutionary trends (Sharma and Mukai, 2015; Stace, 2000). Despite being one of the largest families of angiosperm, cytological analysis has been carried out on no more than $10 \%$ of Orchidaceae (orchids) species due to the relatively high diversity in chromosome numbers and comparatively small or even minute chromosome size (Myo et al., 2011; Tanaka and Kamemoto, 1984). Their patterns of speciation and evolution of the entire Orchidaceae family are still debated because of lack of information on valuable chromosome landmarks (Sharma and Mukai, 2015).

As a genus of Orchidaceae, classification status of Bletilla has also been uncertain for many years (Goldman et al., 2001). Tan (1969) concluded that Bletilla was more closely associated with Bletia purpurea, and Bletilla was placed in the same subtribe (Bletiinae, Arethuseae) with Bletia (Dressler, 1981, 1993) or subtribe Bletiinae (tribe Epidendreae) (van den Berg et al., 2005). With DNA phylogenetic analysis, genus Bletilla is now placed in the updated subtribe Coelogyninae (Chase et al., 2003; Li et al., 2015; van den Berg et al., 2005).

Previous cytological investigations of Bletilla provided the chromosome counts for only two species, without detailed karyotype information. The main chromosome number of B. striata was $\mathrm{n}=16(2 \mathrm{n}=32)$, and intraspecific variation had also been reported, that is, $B$. striata $(2 \mathrm{n}=64$ and 76$)$. B. formosana has a

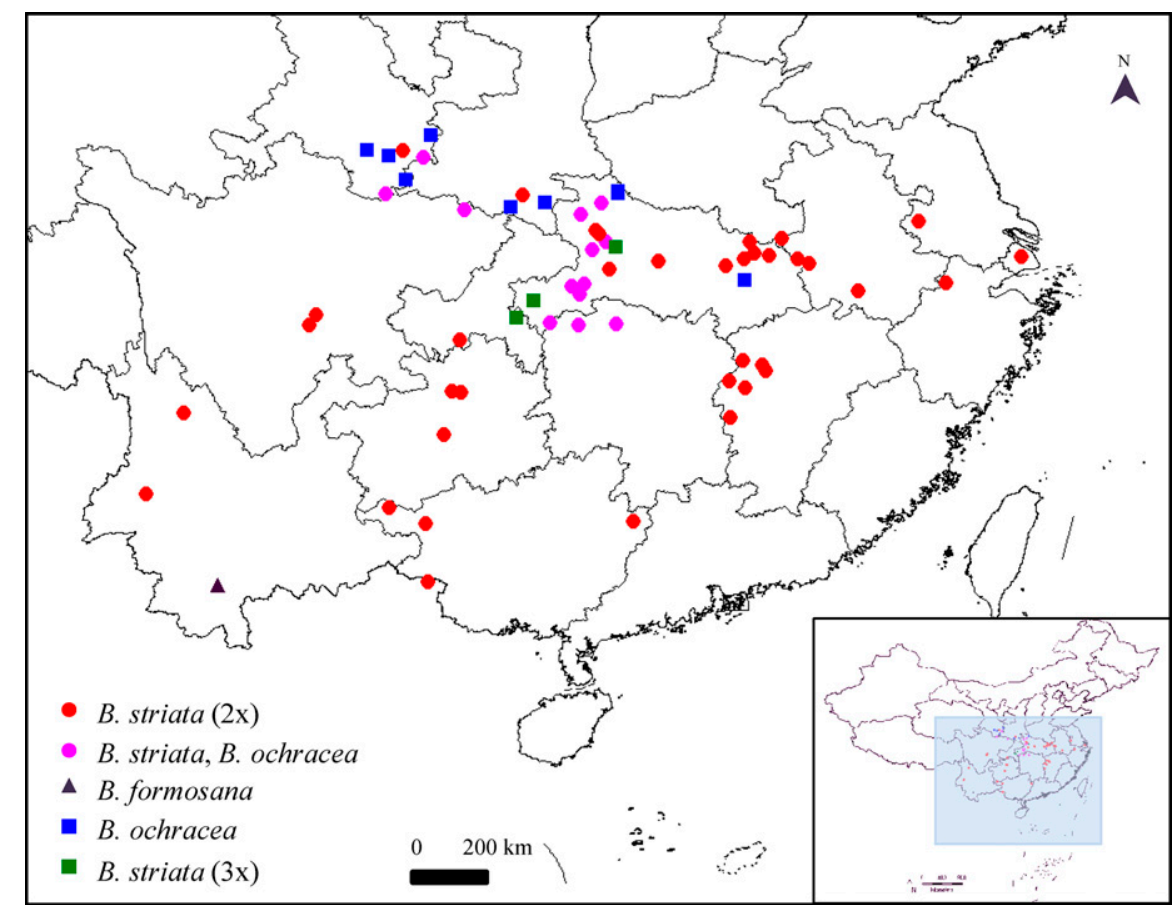

Fig. 1. Geographic distribution and ploidy level of the Bletilla plants collected from China. All population samples were diploid, except for the HBYL, HBLC, and HBEX populations, which had a small proportion of triploid individuals. For location details, see Supplemental Table 1. This map is provided by the International Potato Center (CIP) public domain and is drawn by DIVA-GIS (https:// research.cip.cgiar.org/confluence/display/divagis/Home). 
uniform chromosome number $\mathrm{n}=18(2 \mathrm{n}=36)$ (Felix and Guerra, 2010; Li and Chen, 1987; Tan, 1969). Based on the reported chromosome number variations, a basic chromosome number of $x=16$ was suggested for the genus Bletilla (Felix and Guerra, 2010).

Genome size is another karyotypic character that can vary considerably among species with difference in repetitive DNA amount (Flavell et al., 1974). Species in the orchid family present the second largest genome size variation among plants (168-fold variation) (Leitch et al., 2009) following Melanthiaceae (230-fold variation) (Pellicer et al., 2014). So far, the genome size of only one species of Bletilla has been estimated (B. striata, $1 \mathrm{C}=2.95 \mathrm{pg}$ ), and its patterns of interspecific and intraspecific variations of DNA contents and genome size evolution of the genus are still unclear (Zhang et al., 2013; Zonneveld et al., 2005).

Considering the scarce cytological information available for Bletilla, we carried out a study on the ploidy level, chromosome number, and genome size. Our research aims to provide important information for the further reservation and development of the important medicinal resource of Bletilla plants. In addition, the investigation patterns of DNA content variation and variation in chromosome number can also provide meaningful and essential information to further explore the evolution of genome size and the main mechanisms of chromosome evolution in a phylogenetic context of Bletilla.

\section{Materials and Methods}

Plant materials. Living collections of 1082 plants, including B. striata, B. ochracea, and $B$. formosana, were obtained from 62 locations in China (Fig. 1, Table 1). Due to their extremely narrow distribution and endangered situation, B. foliosa (synonymy $B$. sinensis) could not be collected, and only one population of $B$. formosana was collected in this study. The representative specimens of plants from each population were deposited in the herbarium (HIB) of Wuhan Botanical Garden, Chinese Academy of Sciences. A small number of young roots and leaves were sampled from seedlings for chromosome counting and nuclear DNA content estimation. The ploidy level of all the collected plants was analyzed by flow cytometry (FCM). Chromosome counts, karyotypes, and DNA content analyses were performed on three individuals from each of 25 populations of three species.

Ploidy levels and genome size estimation. Nuclear DNA content was assessed by FCM with minor modifications (Doležel et al., 2007). All procedures were performed at $4{ }^{\circ} \mathrm{C}$ or on ice. Approximately 50 to $100 \mathrm{mg}$ of newly expanding leaf tissue from each sample and/or calibration standard sample was placed in a plastic $60-\mathrm{mm}$ petri dish standing on ice. Ice-cold LB01 buffer [15 mm Tris; $2 \mathrm{~mm}$ $\mathrm{Na}_{2}$ EDTA; $0.5 \mathrm{~mm}$ spermine. $4 \mathrm{HCl} ; 80 \mathrm{~mm}$ $\mathrm{KCl} ; 20 \mathrm{~mm} \mathrm{NaCl} ; 15 \mathrm{~mm} \beta$-mercaptoethanol; $0.1 \%(\mathrm{v} / \mathrm{v})$ Triton X-100; $\mathrm{pH} 7.5$ ] was added in the proportion of $1.5 \mathrm{~mL}$ buffer per $100 \mathrm{mg}$ tissue. Tissues were chopped using a sharp

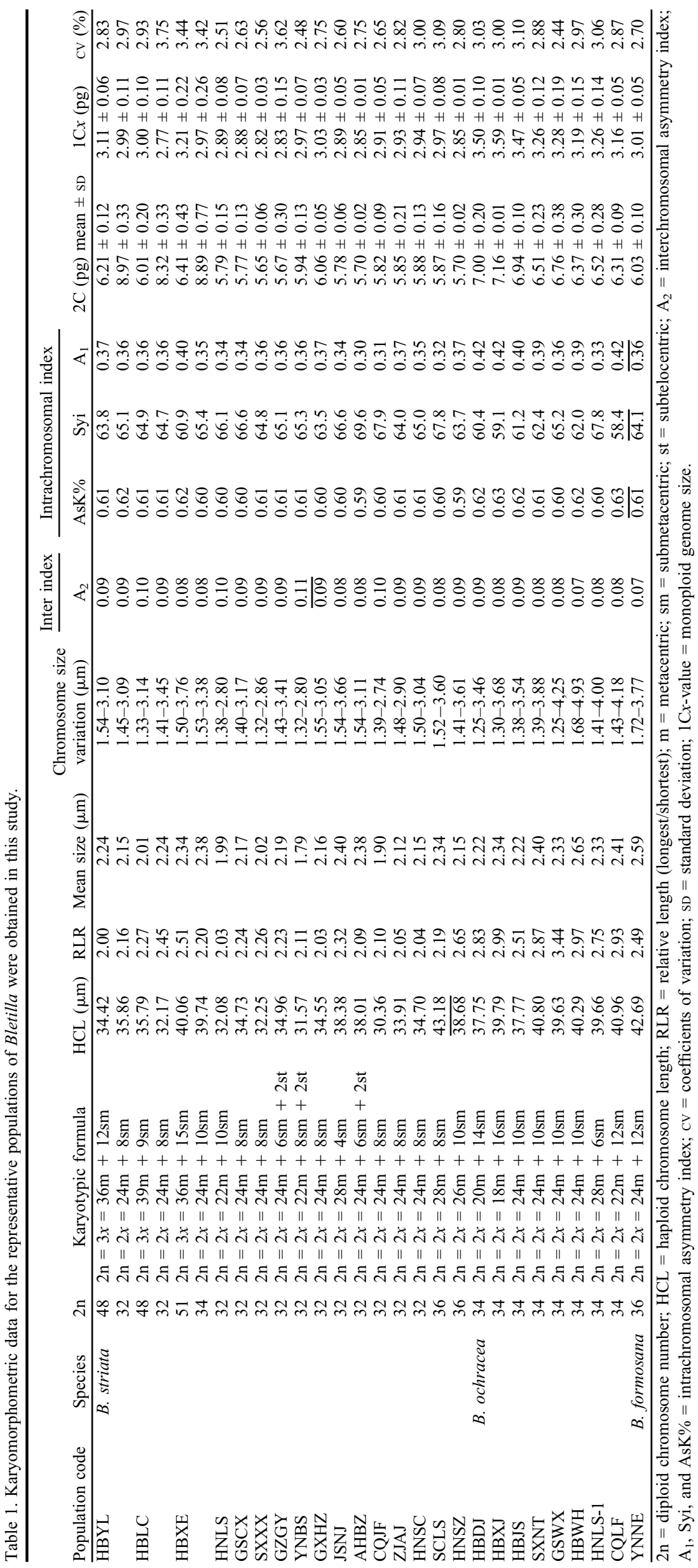


razor blade for 2 to $3 \mathrm{~min}$ and then filtered through a $30-\mu \mathrm{m}$ nylon filter to remove large debris and cell fragments. The homogenate was treated with $50 \mu \mathrm{g} \cdot \mathrm{mL}^{-1}$ RNase A (DNase free) and stained with $50 \mu \mathrm{g} \cdot \mathrm{mL}^{-1}$ propidium iodide (Sigma, St. Louis, MO). Homogenate was incubated for $30 \mathrm{~min}$ in the dark on ice and then measured using a BD Accuri C6 FCM (BD Biosciences, San Jose, CA) equipped with software BD Accuri C6. The known diploid $B$. striata $(2 \mathrm{n}=2 \mathrm{x}=32)$ was used as a standard for define the ploidy levels. A total of 1082 individuals from 62 populations of three species were examined.

FCM was also used to estimate genome size following the method as described previously. Solanum lycopersicum var. 'Stupiché' with a DNA content of $2 \mathrm{C}=1.96 \mathrm{pg}$ (Doležel et al., 1992) was used as an internal standard. Genome sizes of 25 populations of three species were estimated (Table 1), and one or two individuals were analyzed for each population. For each individual, three leaf samples were prepared and each sample was run three times. The fluorescence intensity of more than 10,000 particles was recorded in each run. Based on the peak of internal standard and Bletilla species, experimental genome size was calculated using the following equation: $2 \mathrm{C}=(\mathrm{G} 1$ peak value of sample/G1 peak value of standard) $\times 2 \mathrm{C}$ genome size of standard (pg DNA) The term "monoploid genome size" $(1 \mathrm{C} x)$ was used to represent the DNA content in a basic chromosome set $(x)$ of a somatic cell (Greilhuber et al., 2005), whereas $2 \mathrm{C}$ referred to the whole genome size of a somatic cell. Data collection was performed using software BD Accuri C6.

Chromosome preparation. Active root tips were sampled from representative individuals and immediately placed in a saturated solution of P-dichlorobenzene for $8 \mathrm{~h}$ at $4{ }^{\circ} \mathrm{C}$ in the dark. Roots were fixed for a minimum of $2 \mathrm{~h}$ in fresh absolute ethanol/glacial acetic acid $(3: 1, \mathrm{v} / \mathrm{v})$ at $4{ }^{\circ} \mathrm{C}$ and then transferred to a $70 \%$ ethanol solution. To prepare slides, the fixed root tips were hydrolyzed at $60^{\circ} \mathrm{C}$ in $1 \mathrm{~N} \mathrm{HCl}$ for 6 to $8 \mathrm{~min}$ and stained in carbol-fuchsin solution. Finally, root tips were squashed for cytological observation. Prepared materials were analyzed under an Olympus Microscope (BX53/Flex; Tokyo, Japan), and chromosome images with well-spread metaphases were captured using a computer-assisted cooled chargecoupled devise camera using cellSens software. Chromosome counts were performed on one to two representative individuals from the preceding 25 populations.

Chromosome measurement. At least five spread metaphases with clear and separate chromosomes were examined for chromosome number and karyotypic asymmetry. Karyotype features included chromosome number (2n), HCL, and Stebbins karyotype (SK) (MedeirosNeto et al., 2017; Stebbins, 1971), and the asymmetric indexes were selected as follows: interchromosomal asymmetry indexes $\mathrm{A}_{2}$, intrachromosomal asymmetry indexes $\mathrm{A}_{1}$ (Zarco, 1986), Syi (Venora et al., 2002), and asymmetry coefficient of karyotypes AsK\% (Arano, 1963). The arm ratio $(r=$ length of the long arm/length of the short arm) was used to classify the chromosomes as metacentric ( $\mathrm{m}, \mathrm{r}=1.0$ to 1.7 ), submetacentric ( $\mathrm{sm}, \mathrm{r}=1.7$ to 3.0 ), subtelocentric (st, $r=3.0$ to 7.0), and asrocentric ( $\mathrm{t}, \mathrm{r}=7.0$ to $\infty$ ) (Levan et al., 1964).

Phylogenetic analysis. A phylogenetic analysis based on its internal transcribed spacer (ITS), mat $\mathrm{K}$ and $t r n \mathrm{~L}$ refers to the sequence information of ( $\mathrm{Li}$ et al., 2015) and the detailed information is listed in Supplemental Table 2. Arethusa bulbosa was used as outgroup. The analyses were performed using the maximum likelihood (ML) criterion implemented in MEGA-X.
Conflicts were explored through visual examination of resulting ML trees and comparison of nodes with $>70 \%$ bootstrap support.

Statistical analysis. Analysis of variance (ANOVA) and Student's $t$ test at 5\% probability level were conducted through SPSS software (SigmaStat for Windows Version 20.1; SPSS Inc., Richmond, CA). Duncan's multiple-range test was also used to identify the significant differences among the means via the statistical program.

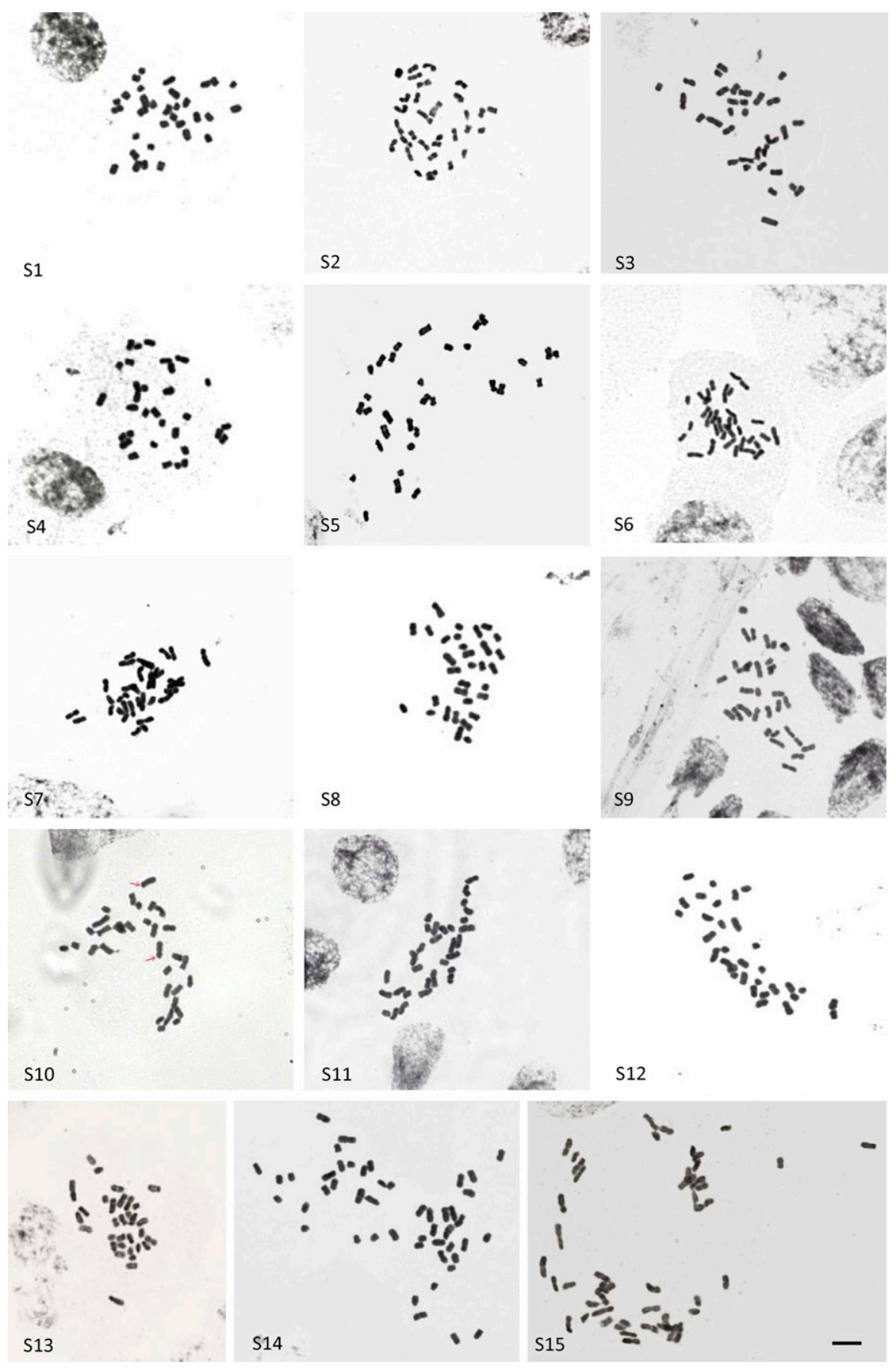

Fig. 2. Metaphase chromosomes of Bletilla striata representative samples obtained from 13 populations in China. S1-S13: All samples were diploid with $2 \mathrm{n}=2 \mathrm{x}=32$; S1 to S13 display GSCX, AHBZ, GXHZ, GZGY, HNLS, JSNJ, SXXX, YNBS, HNSC, CQJF, ZJAJ, HBYL-14, and HBLC-21 in order. S14-S15: Triploid samples of HBYL and HBLC populations with $2 \mathrm{n}=3 \mathrm{x}=48$ (HBYL-65 and HBLC-15). Arrows represent satellites. Scale bar: $5 \mu \mathrm{m}$. 


\section{Results and Discussion}

DNA ploidy level and chromosome counts. The DNA ploidy levels of 1082 individuals from 62 locations by FCM and the $\mathrm{C} x$ nuclear DNA contents of all populations are shown in Supplemental Table 1. The $\mathrm{C} x$-value was defined as the DNA content of a monoploid genome with chromosome number $x$ (Greilhuber et al., 2005). Results showed that all the populations of $B$. striata had $2 \mathrm{Cx}$ nuclear DNA content except for three populations in Western Hubei (HBYL, HBLC, and HBXE), which showed two DNA ploidy levels, and $5.8 \%, 18.3 \%$, and $6.3 \%$ of individuals in these populations, respectively, had $3 \mathrm{C} x$ nuclear DNA content. For B. ochracea and B. formosana, all individuals had $2 \mathrm{C} x$ nuclear DNA content, and no tetraploid or higher ploidy was found among the Bletilla samples.

Chromosome counting of representative individuals from 25 populations confirmed that most populations of $B$. striata were diploid with $2 \mathrm{n}=2 \mathrm{x}=32$, whereas small proportions of individuals were triploids $(2 \mathrm{n}=3 \mathrm{x}=$ 48) from HBYL and HBLC populations (Figs. 2 and 4A). Individuals of the HBXE population demonstrated dysploidy $2 \mathrm{n}=2 \mathrm{x}=$ 34 , and $6.3 \%$ individuals were triploid $(2 \mathrm{n}=$ $3 \mathrm{x}=51)$. Dysploidy was found in a small number of individuals $(2 \mathrm{n}=2 \mathrm{x}=36)$ from SCLS and HNSZ populations (Figs. 3 and 4C). B. ochracea and B. formosana were all diploid with $2 \mathrm{n}=2 \mathrm{x}=34$ and $2 \mathrm{n}=2 \mathrm{x}=36$, respectively (Figs. 3, 4B, and 4D). Bletilla had moderate chromosomal variation levels, with basic chromosome numbers of $\mathrm{x}=16$, 17 , and 18. B. striata showed more chromosome diversity than other species.

Karyotype. Metaphase chromosome morphologies of the 25 populations are shown in Figs. 2-4, and their karyotype formulae and related parameters are listed in Table 1. All chromosomes of Bletilla were small with lengths ranging from $1.25 \mu \mathrm{m}$ to $4.93 \mu \mathrm{m}$ in B. ochracea. Their chromosomes consisted of three types, including metacentric (m), submetacentric (sm), and subtelocentric (st). HCL ranged from $30.36 \mu \mathrm{m}$ to $43.18 \mu \mathrm{m}$ in $B$. striata. All individuals of $B$. striata possessed $\mathrm{m}$ and $\mathrm{sm}$ chromosomes with percentages of $88 \%$ and $10 \%$, respectively, and three of these individuals exhibited $\mathrm{m}$, sm, and st chromosomes (Table 1). The karyotypes of $B$. striata were mainly characterized by $2 \mathrm{n}=2 \mathrm{x}=32=$ $24 \mathrm{~m}+8 \mathrm{sm}$ and $2 \mathrm{n}=2 \mathrm{x}=32=24 \mathrm{~m}+6 \mathrm{sm}+$ 2 st. For individuals demonstrating dysploidy, karyotypes were characterized by $2 \mathrm{n}=2 \mathrm{x}=$ $34=24 \mathrm{~m}+10 \mathrm{sm}$ and $2 \mathrm{n}=2 \mathrm{x}=36=28 \mathrm{~m}+$ $8 \mathrm{sm}$. For B. ochracea and B. formosana, their karyotypes were mainly characterized by $2 \mathrm{n}=$ $2 \mathrm{x}=34=24 \mathrm{~m}+10 \mathrm{sm}$ and $2 \mathrm{n}=2 \mathrm{x}=36=$ $24 \mathrm{~m}+12 \mathrm{sm}$. There was one pair of satellites located on the short arms of two $B$. ochracea and two B. striata (Figs. 3 O3, 3 O4, 3 D3, and $2 \mathrm{~S} 10)$.

Regarding interchromosomal asymmetry $\left(\mathrm{A}_{2}\right)$, the most symmetric karyotype was found in B. formosana and B. ochracea $\left(\mathrm{A}_{2}=0.07\right)$, whereas the most asymmetrical was found in B. striata $\left(\mathrm{A}_{2}=0.11 ;\right.$ Table 1$)$. For

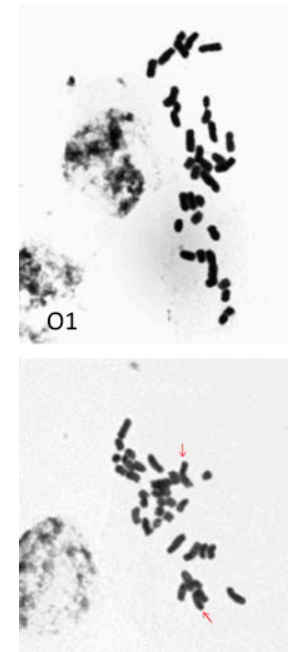

04

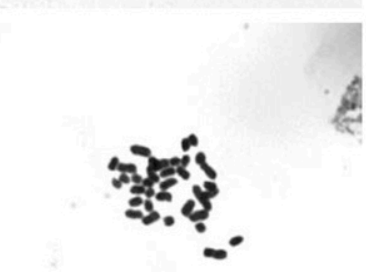

07

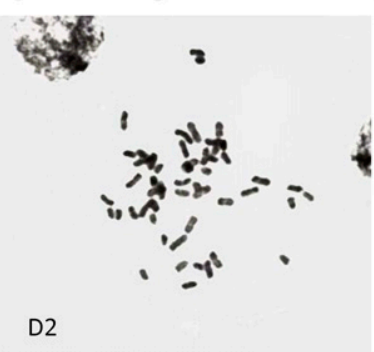

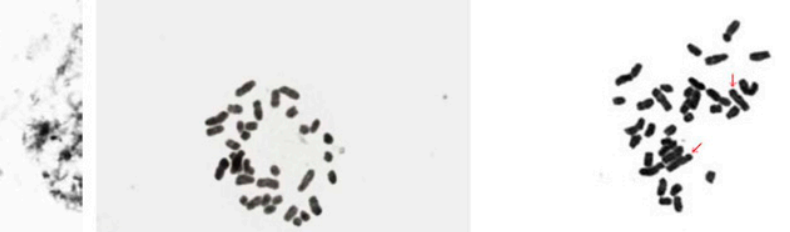

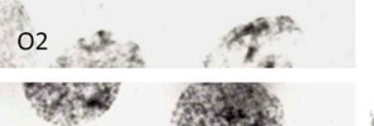

03

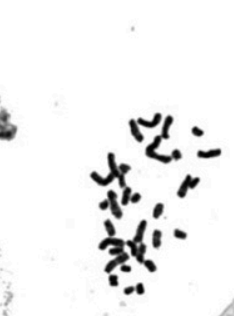

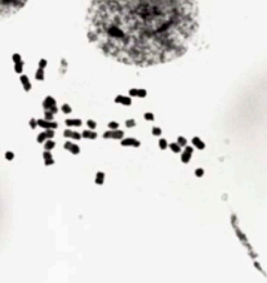

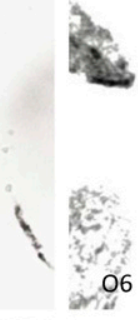

$\mathrm{O} 8$
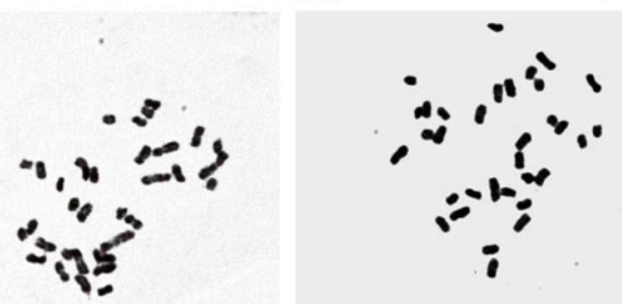

D1

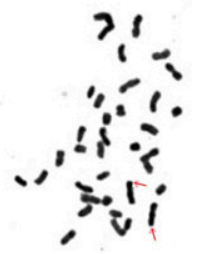

D3

D4

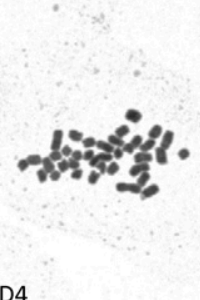

$\bullet$

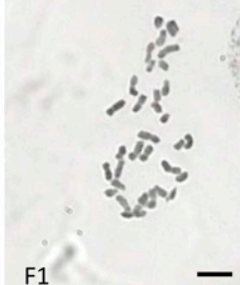

Fig. 3. Metaphase chromosomes of other samples obtained from another 13 populations. O1-O8: All the Bletilla ochracea samples were diploid with $2 \mathrm{n}=2 \mathrm{x}=34$ (CQLF, HBDJ, HBXJ, GSWX, HBJS, SXNT, HNLS, and HBWH). D1-D2: dysploidy samples and their triploids with $2 \mathrm{n}=2 \mathrm{x}=$ $34,2 \mathrm{n}=3 \mathrm{x}=51$ (HBXE-10 and HBXE-20); D3-D4: dysploidy $2 \mathrm{n}=2 \mathrm{x}=36$ (SCLS, HNSZ). F1: Bletilla formosana $2 \mathrm{n}=2 \mathrm{x}=36$ (YNNE). Arrows represent satellites. Scale bar: $5 \mu \mathrm{m}$.

intrachromosomal asymmetry indexes, AsK\% and $\mathrm{A}_{1}$ showed that $B$. striata had the minimum mean values $(0.61$ and 0.35$)$, whereas the maximum mean values $(0.62$ and 0.39$)$ were found in B. ochracea. Analysis of karyotype symmetry showed that $B$. striata had the maximum Syi mean value (65.18), and the minimum mean value (62.06) was found in $B$. ochracea. In addition, the AsK\%, $\mathrm{A}_{1}$ and Syi karyotype parameters of $B$. formosana were $0.61,0.36$, and 64.10 , respectively. The most symmetric karyotype was found in B. striata and the most asymmetric karyotype was found in B. ochracea (Fig. 5, Table 1).

Nuclear DNA content. Nuclear DNA contents were determined for the 25 selected populations (Fig. 6A, Table 1). The mean $1 \mathrm{C} x$ (monoploid genome size) nuclear DNA content of $B$. striata was $2.94 \mathrm{pg}$. B. striata had a diploid cytotype $(2 \mathrm{n}=2 \mathrm{x}=32)$ and a triploid $(2 \mathrm{n}=3 \mathrm{x}=48)$ cytotype, with mean $1 \mathrm{C} x$ nuclear DNA contents of $2.94 \mathrm{pg}$ and
$2.91 \mathrm{pg}$, respectively. The nuclear DNA contents within the diploid cytotype of $B$. striata varied from 2.82 to $3.11 \mathrm{pg}$, whereas the variation in the triploid cytotype was from 2.77 to $2.99 \mathrm{pg}$. The variation of the mean $1 \mathrm{Cx}$ nuclear DNA content in triploid samples was smaller than that in diploid samples but not significant. For the dysploidy of $B$. striata, the mean $1 \mathrm{C} x$ nuclear DNA contents of its diploid cytotype $(2 \mathrm{n}=2 \mathrm{x}=34)$ and triploid $(2 \mathrm{n}=3 \mathrm{x}=51)$ cytotype were $2.97 \mathrm{pg}$ and $3.21 \mathrm{pg}$, respectively. The highest mean $1 \mathrm{C} x$ of B. ochracea $(2 \mathrm{n}=2 \mathrm{x}=34)$ with nuclear DNA content of $3.33 \mathrm{pg}$ was determined, which varied by 1.14 -fold among different populations (from 3.16 to $3.59 \mathrm{pg}$ ). For $B$. formosana $(2 \mathrm{n}=2 \mathrm{x}=36)$, the mean $1 \mathrm{C} x$ nuclear DNA content was $3.01 \mathrm{pg}$. The $\mathrm{CV}$ ranged from $2.11 \%$ to $4.13 \%$.

The ANOVA and Student's $t$ test showed that there were significant differences in nuclear DNA content between B. ochracea and B. striata, 
S1

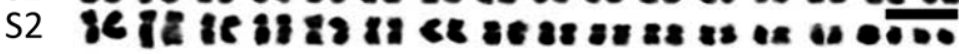

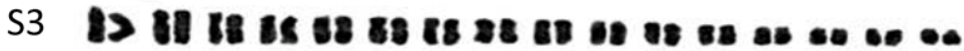

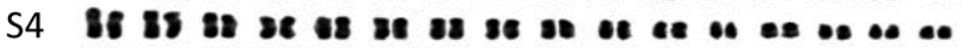

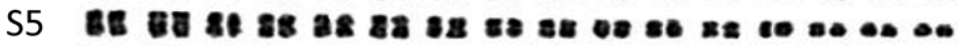

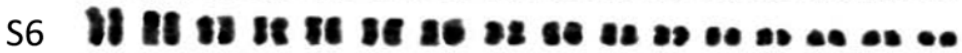

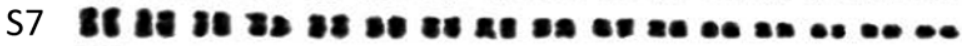

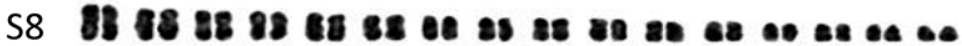

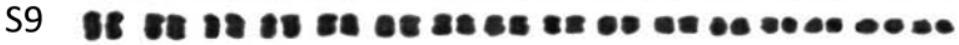

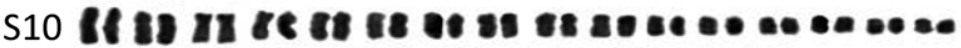

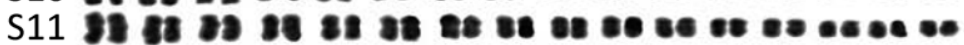

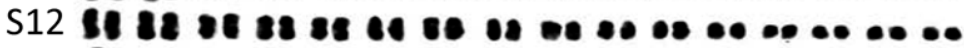

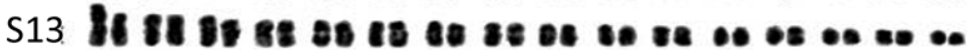
$\begin{array}{llllllllllllllll}1 & 2 & 3 & 4 & 5 & 6 & 7 & 8 & 9 & 10 & 11 & 12 & 13 & 14 & 15 & 16\end{array}$

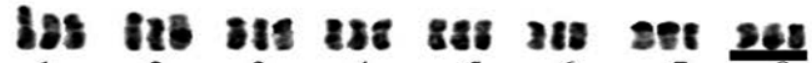

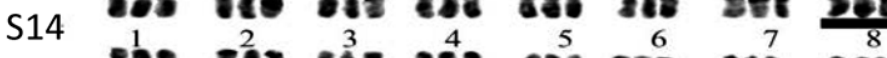

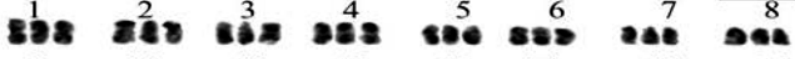
$\begin{array}{llllllll}9 & 10 & 11 & 12 & 13 & 14 & 15 & 16\end{array}$

S15

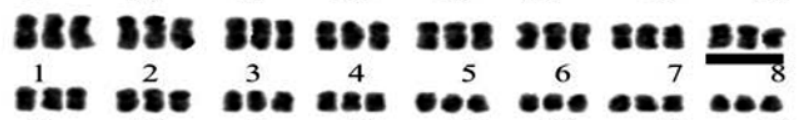

$\begin{array}{llllllll}9 & 10 & 11 & 12 & 13 & 14 & 15 & 16\end{array}$

B

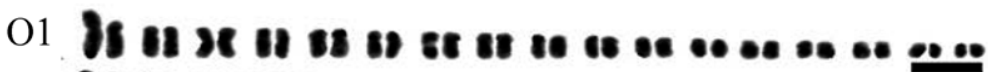

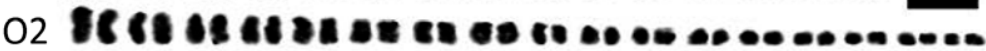

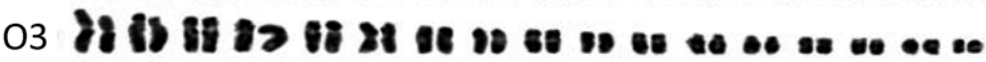

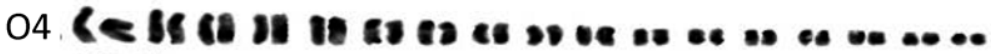

O5 86 לנ

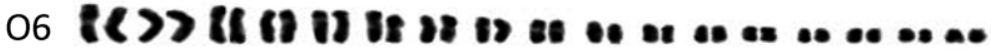

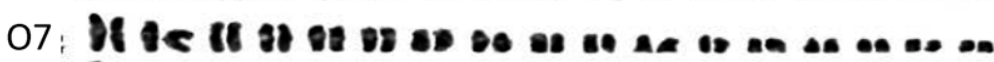

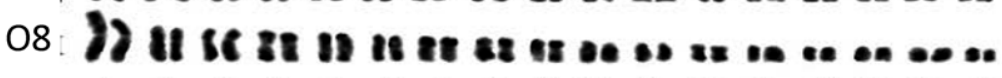

C

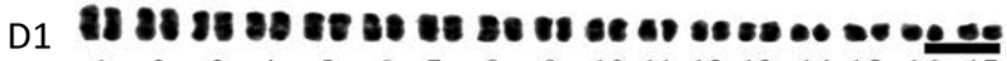
$\begin{array}{llllllllllllllllll}1 & 2 & 3 & 4 & 5 & 6 & 7 & 8 & 9 & 10 & 11 & 12 & 13 & 14 & 15 & 16 & 17\end{array}$

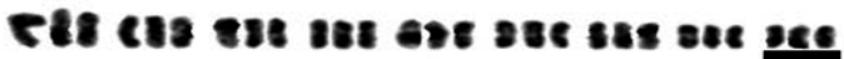

D2

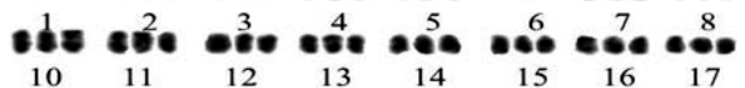

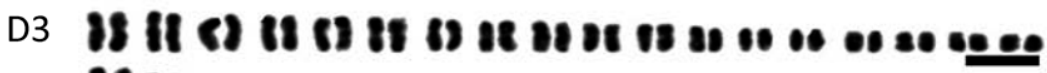

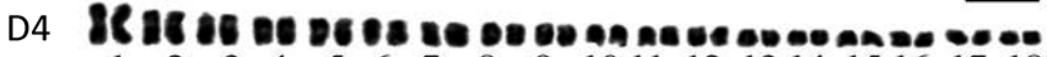

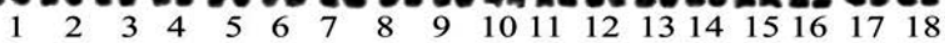

D

F1 286898 LE

Fig. 4. Karyotypes of wild Bletilla samples from 25 populations in China. (A) Bletilla striata $2 \mathrm{n}=2 \mathrm{x}=$ $32,2 \mathrm{n}=3 \mathrm{x}=48$. (B) Bletilla ochracea $2 \mathrm{n}=2 \mathrm{x}=34$. (C) Dysploidy of B. striata $2 \mathrm{n}=2 \mathrm{x}=34$ and $2 \mathrm{n}=3 \mathrm{x}=51,2 \mathrm{n}=2 \mathrm{x}=36$. (D) Bletilla formosana $2 \mathrm{n}=2 \mathrm{x}=36$. There were two satellites on the short arms of chromosome 2 of B. striata (codes AS10 and CD3). For B. ochracea, the two satellites are located on the short arms of chromosome 3 and chromosome 1 of codes $\mathbf{B O} 3$ and $\mathbf{B O} 4$, respectively. Scale bar: $5 \mu \mathrm{m}$.

and B. ochracea and B. formosana $(P<0.05)$, whereas the difference between $B$. striata and $B$. formosana was not significant (Fig. 6B, Table 1).
Relation between genome sizes and karyological characteristics. No obvious correlation between monoploid genome sizes (1Cx)

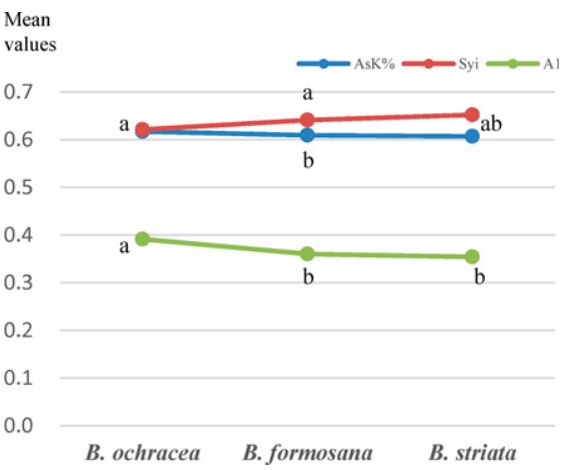

Fig. 5. Intrachromosome asymmetry values obtained by karyotype asymmetry index (AsK\%) (blue), Syi (red), and A1 (green) indexes for Bletilla. The numeric scale at the right side indicates the mean value for the four indexes. The Syi value was divided by 100 . Species indicated by the same letters are not significantly different (Duncan test, $P<0.05$ )

vs. ploidy levels and chromosome numbers was showed by a linear regression model. However, a positive correlation $(r=0.49$; $P=0.013, F=0.013$ ) between $1 \mathrm{C} x$ and HCL in Bletilla (Fig. 7A) and between $1 \mathrm{Cx}$ and AsK\% $(r=0.58 ; P=0.0014, F=0.0014)$ was found (Fig. 7B).

Evolution of chromosome numbers and genome size. Phylogenetic analyses based on ITS, matK and $t r n \mathrm{~L}$ were made following $\mathrm{Li}$ et al. (2015). The strict consensus tree from parsimony ratchet analysis with bootstrap support values for individual branches is shown in Fig. 8. Combining these chromosome numbers and genome size data with those from the literature and superimposing them on the phylogenetic tree (Fig. 8) showed that most of the species with counts were diploid with different chromosome numbers (i.e., B. ochracea, $2 \mathrm{n}=$ $2 \mathrm{x}=34 ; B$. formosana, $2 \mathrm{n}=2 \mathrm{x}=36$ ). In addition to the diploids $(2 \mathrm{n}=2 \mathrm{x}=32)$, the triploid $(2 \mathrm{n}=3 \mathrm{x}=48,51)$ and dysploidy $(2 \mathrm{n}=34,36)$ arisen by chromosome fission were detected in the B. striata.

B. ochracea showed an increase in $2 \mathrm{C}$ DNA content with an increase in the chromosome number, whereas $B$. formosana with the largest chromosome number had a relatively small $2 \mathrm{C}$ value $(2 \mathrm{C}=6.02)$. An obvious correlation between the chromosome number and nuclear DNA content could not be drawn from the present investigation.

Our results supported the earlier views that $B$. striata mainly has a karyotype of $2 \mathrm{n}=2 \mathrm{x}=$ 32 , and $B$. formosana mainly has a karyotype of $2 n=2 x=36$ (Figs. 2 and 3, Table 1) (Felix and Guerra, 2010; Li and Chen, 1987; Li et al., 1992; Tan, 1969; Tanaka, 1971), but we did not find the previously reported chromosome numbers of $B$. striata $(2 \mathrm{n}=64$ and 76$)$ (Felix and Guerra, 2010; Li and Chen, 1987; Li et al., 1992). Karyotype data for B. ochracea $(2 n=2 x=34)$ was reported for the first time in the present study. All the samples of B. ochracea and B. formosana were diploid, which may be due to the small num- 
A

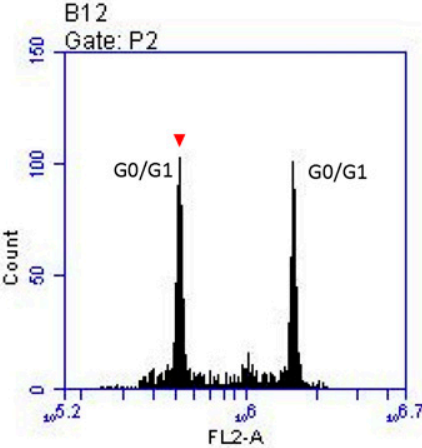

B. striata

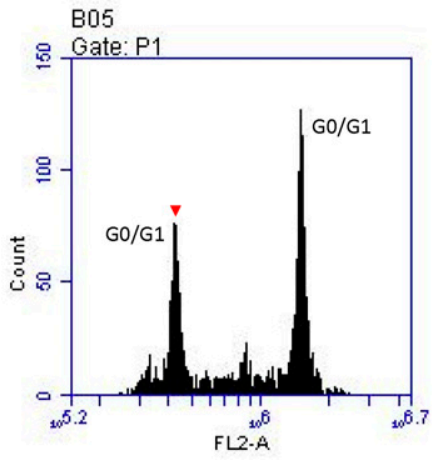

B. ochracea

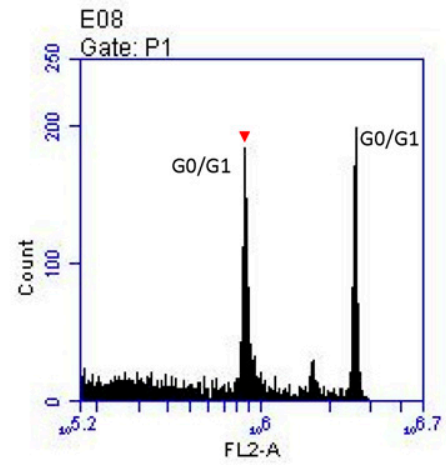

B. formosana

B

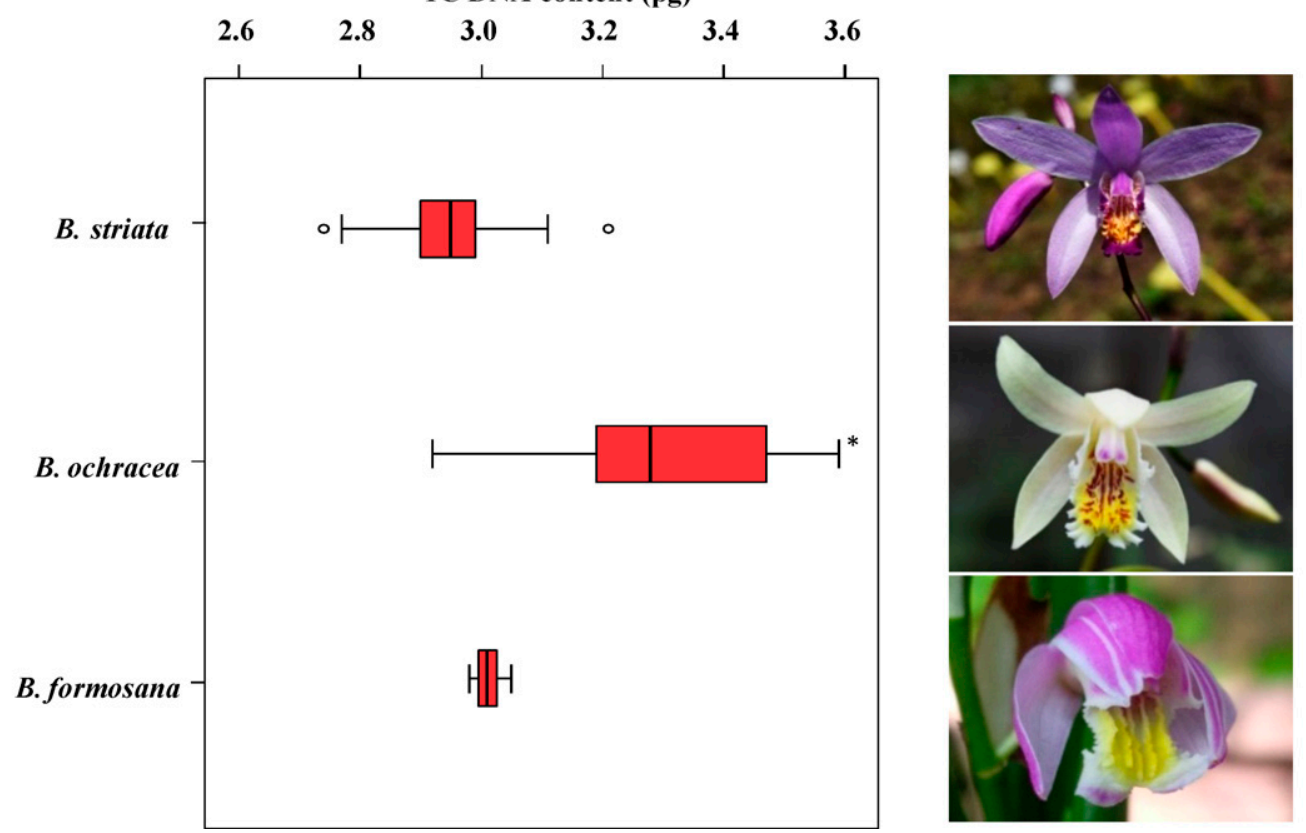

Fig. 6. Estimation of genomic size in the genus Bletilla. (A) DNA histogram showing G0/G1 peaks resulting from simultaneous processing and analysis of nuclear suspensions of tissue from young leaves stained with propidium iodide. Bletilla striata $(2 \mathrm{C}=5.88 \mathrm{pg})$, Bletilla ochracea $(2 \mathrm{C}=6.66 \mathrm{pg})$, and Bletilla formosana $(2 \mathrm{C}=6.03 \mathrm{pg})$. Solanum lycopersicum L. $(2 \mathrm{C}=1.96 \mathrm{pg}$, marked with triangles) was used as an internal standard. (B) Box plot of $1 \mathrm{C} x$ values (pg) of Bletilla. Genome size estimate range for each species; asterisks indicate that there is a significant difference (least significant difference test, $P<0.05$ ). The ends of the horizontal lines indicate the minimum and maximum data values. Circles indicate outliers. The mean $1 C x$ nuclear DNA contents of $B$. striata, $B$. ochracea, and B. formosana are $2.94,3.33$, and $3.01 \mathrm{pg}$, respectively. The right side corresponds to the flower characteristics of each species.

bers of samples collected. B. striata showed a relatively high chromosome number diversity, which is consistent with the view that the species characterizes by a wide geographic

A

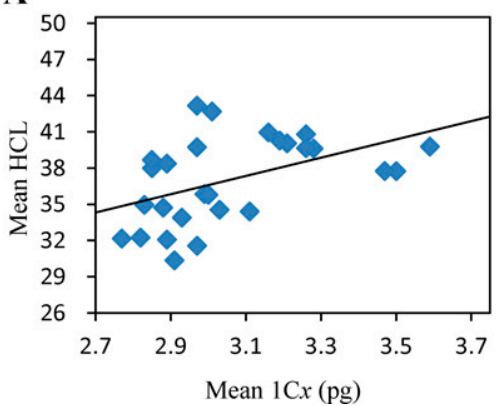

distribution and shows greater karyomorphological variation than species with restricted distributions (Oliveira et al., 2010; Turco et al., 2018).

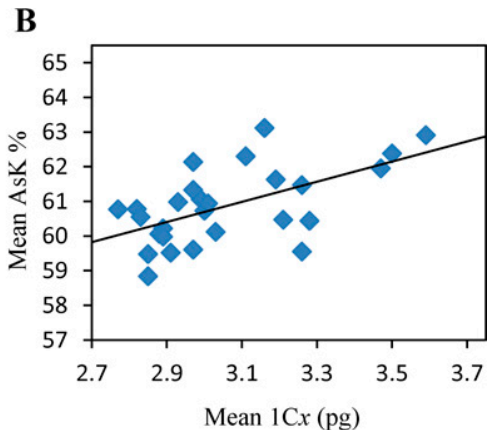

Fig. 7. Relationship between genome size (1Cx) and karyotype features, namely, (A) chromosome total haploid length (HCL) and (B) karyotype asymmetry index (AsK\%).
In nature, odd polyploidy usually originates from fusion of unreduced gametes with regularly reduced gametes and is maintained by apomictic or vegetative propagation (Faehnrich et al., 2019; Ramsey and Schemske, 1998; Wang et al., 2018). The capability of Bletilla to multiply asexually through rhizomes would enhance the likelihood that a low frequency $(\approx 5.8 \%$ to $18.3 \%)$ of triploids originates and is maintained in natural populations. Polyploidization, a widespread phenomenon among plants, is considered a major speciation mechanism (Kohler et al., 2010). In particular, autotetraploids may originate from mattings involving viable triploids (unilateral polyploidization), which in turn results from the fusion of $\mathrm{n}$ and $2 \mathrm{n}$ gametes produced by diploids (triploid bridge hypothesis) (Harlan, 1975; Kovalsky et al., 2018). Our discovery of considerable proportion of triploid plants in the diploid population implied that unilateral polyploidization through a triploid bridge 


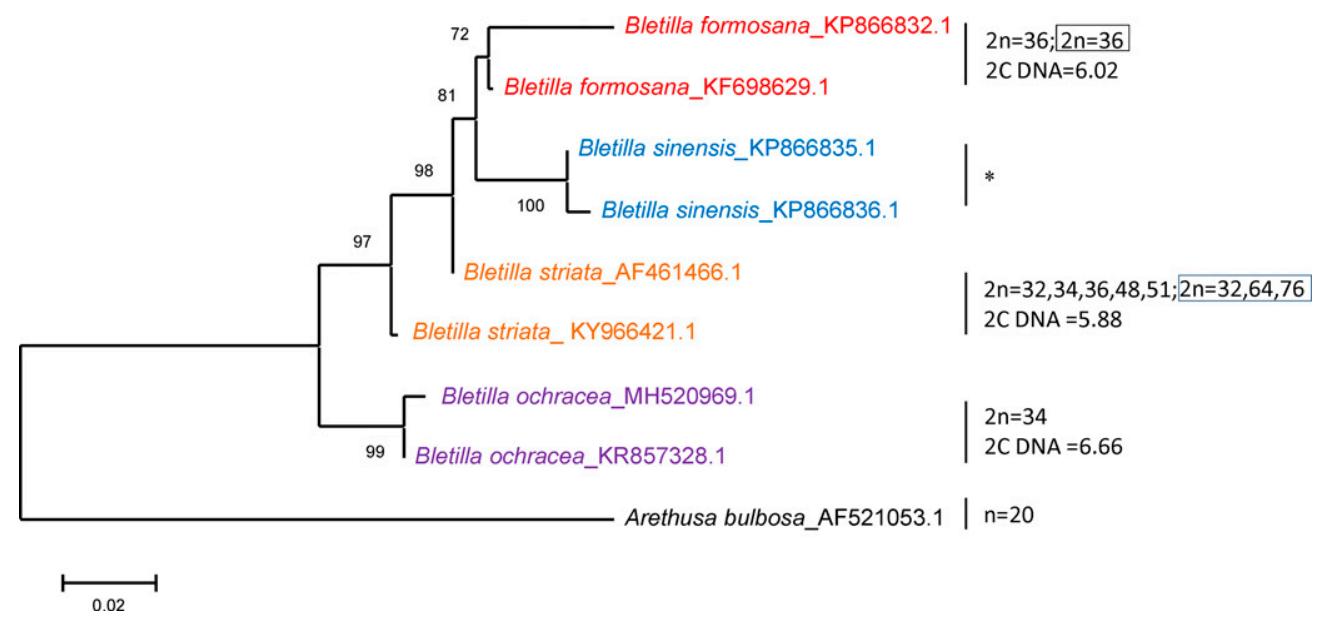

Fig. 8. A phylogenetic maximum likelihood (ML) tree constructed using MEGA-X based on the internal transcribed spacer (ITS), matK and trnL sequence of four Bletilla species including Arethusa bulbosa as an outgroup. Numbers on the branches indicate bootstrap. The chromosome and genome size of the corresponding species are marked on the left side of the phylogenetic tree. Chromosome numbers from Felix and Guerra (2010) are marked with a rectangle and the others obtained in this study. *Indicates no chromosomal and genomic data have been obtained, currently.

might be an alternative mechanism of polyploid formation in complexes, which was supported by our observation that triploids of $B$. striata are not completely sterile. In addition, all the detected triploids, dysploids, and mixed-distribution populations of $B$. striata and B. ochracea were mainly distributed in southeast Sichuan, northwest Hunan, and southwest Hubei, which are the main areas of the important biodiversity center of east Sichuan-west Hubei. The results showed that this area of east Sichuan-west Hubei is likely the genetic diversity center of Bletilla.

The variations in chromosome numbers also reflected frequent dysploidy events detected in Orchidaceae (Felix and Guerra, 2010; Mandakova and Lysak, 2018; Moraes et al., 2017). Dysploids with $2 \mathrm{n}=2 \mathrm{x}=36$ and $2 \mathrm{n}=2 \mathrm{x}=34$ in $B$. striata were found in this study. Dysploidy is an increase or decrease in the chromosome number as a result of structural rearrangements (Shan et al., 2003; Yang et al., 2014; Yeh et al., 2017). Our information on the nuclear DNA contents of $B$. striata showed that the $2 \mathrm{C}$ values in populations with dysploidy $(2 \mathrm{n}=2 \mathrm{x}=$ $34 ; 2 \mathrm{n}=2 \mathrm{x}=36$ ) were not significantly different from those in other $B$. striata populations with $2 \mathrm{n}=2 \mathrm{x}=32$ (Table 1). Indeed, dysploidy events are considered the most important chromosome evolutionary mechanism in Orchidaceae (Grabiele et al., 2013; Moraes et al., 2017), and the increase from $2 \mathrm{n}=32$ to $2 \mathrm{n}=36$ in $B$. striata was consistent with this hypothesis. Therefore, to fully support polyploidy and dysploidy as important evolutionary mechanisms in the genus Bletilla, chromosome banding techniques and/or in situ hybridization need to be used, which will enable particular chromosome rearrangements to be tracked. A moderate level of chromosomal variation of the genus Bletilla was shown in our article, with basic chromosome numbers of $x=16,17$, and 18 , and further determination of the original basic number will be very meaningful for exploring the ancestral types, evolutionary directions, and pathways of Bletilla.

This study revealed nuclear DNA content values for three species of Bletilla, especially first time for $B$. ochracea and $B$. formosana. $B$. striata, with $1 C x$-values of 2.94 pg $(2 \mathrm{n}=$ $2 \mathrm{x}=32$ ), showed obviously smaller nuclear DNA than $B$. ochracea $(2 \mathrm{n}=2 \mathrm{x}=34)$, with $1 \mathrm{C} x$-values of $3.33 \mathrm{pg}$, and $B$. formosana $(2 \mathrm{n}=2 \mathrm{x}=36)$, with $1 \mathrm{C} x$-values of $3.01 \mathrm{pg}$ (Table 1, Fig. 6). Despite substantial karyotypic differences and base chromosome number variation, there was no significant difference in genome sizes between $B$. striata and B. formosana, which proved that the genome size is not necessarily positively correlated with the number of chromosomes (Leitch et al., 2009). Previous studies have found that a strong correlation exists between the 1Cx value and HCLs in many plants (Levin, 2002). In this study, a positive correlation $(r=0.56 ; P=0.0048)$ was identified between $1 \mathrm{C} x$ and HCL in Bletilla (Fig. 7A), and the positive correlation ( $r=$ $0.58 ; P=0.0014$ ) found between $1 \mathrm{C} x$ and AsK $\%$ indicated that additional DNA was mainly added to the long arm in Bletilla (Fig. 7B) (Du et al., 2017; Peruzzi et al., 2009).

The production of a phylogeny provides a useful framework to examine the evolution of genome size and chromosome number in Bletilla. The different karyotype characters observed in Bletilla were mapped directly onto the molecular phylogenetic tree proposed for this genus (Li et al., 2015) (Fig. 8). The genus showed a variation in chromosome number from $2 \mathrm{n}=32$ to 76 and genome size from $1 \mathrm{C}=2.94 \mathrm{pg}$ to $3.33 \mathrm{pg}$. Based on the reported chromosome number variation, a basic chromosome number of $x=16$ has been suggested for genus Bletilla (Felix and Guerra, 2010). The ascension from $2 \mathrm{n}=32$ to $2 \mathrm{n}=36$ in the genus Bletilla is consistent with this previous research that dysploidy has been suggested to be the main cause of chromosome number variation in Orchidaceae (Felix and Guerra, 2010). In addition, two different mechanisms of dysploidy $(2 \mathrm{n}=34$, $36)$ and polyploidy $(2 \mathrm{n}=48,51,64,76)$ were found in the $B$. striata. In Bletilla, the variation of chromosome number is predominantly a result of dysploidy, and polyploidy also plays a role in its chromosomal evolution. In summary, our research proved that dysploidy and polyploidy was involved in the diversity generation of the chromosome numbers, and there was no clear correlation between chromosome numbers and genome size.

\section{Literature Cited}

Arano, H. 1963. Cytological studies in subfamily Carduoideae (Compositae) of Japan IX. Bot. Mag. Tokyo 76:32-39, https://doi.org/10.15281/ jplantres1887.76.32.

Chase, M.W., K.M. Cameron, R.L. Barrett, and J.V. Freudenstein. 2003. DNA data and Orchidaceae systematics: A new phylogenetic classification, p. 69-89. In: K.M. Dixon, S.P. Kell, R.L. Barrett, and P.J. Cribb (eds.) Orchid conservation. Natural History Publications), Kota Kinabalu.

Chen, X., S. Gale, and P. Cribb. 2009. Flora of China. Missouri Botanical Garden Press, St. Louis; Science Press, Beijing. 25:209-210.

Chen, Z., Y. Zhao, M. Zhang, X. Yang, P. Yue, D. Tang, and X. Wei. 2020. Structural characterization and antioxidant activity of a new polysaccharide from Bletilla striata fibrous roots. Carbohydr. Polym. 227:115362, https://doi.org/ 10.1016/j.carbpol.2019.115362.

Doležel, J., J. Greilhuber, and J. Suda. 2007. Estimation of nuclear DNA content in plants using flow cytometry. Nat. Protoc. 2:2233-2244, https://doi.org/10.1038/nprot.2007.310.

Doležel, J., S. Sgorbati, and S. Lucretti. 1992. Comparison of three DNA fluorochromes for flow cytometric estimation of nuclear DNA content in plants. Physiol. Plant. 85:625-631, https://doi. org/10.1111/j.1399-3054.1992.tb04764.x.

Dressler, R. 1981. The orchids natural history and classification. Harvard University Press, Cambridge, MA.

Dressler, R. 1993. Phylogeny and classification of the orchid family. Cambridge University Press, Cambridge, UK. 
Du, Y.P., Y. Bi, M.F. Zhang, F.P. Yang, G.X. Jia, and X.H. Zhang. 2017. Genome size diversity in Lilium (Liliaceae) is correlated with karyotype and environmental traits. Front. Plant. Sci. 8:1303, https://doi.org/10.3389/fpls.2017.01303.

Faehnrich, B., L.G. Otto, C. Franz, E. Mesic, A.C. Cosendai, and C. Dobes. 2019. Auxin application in interploidy crosses and genome stability: Across-generation investigations on German chamomile (Matricaria recutita [L.] Rauschert) of various origins. Euphytica 215:16, https://doi. org/10.1007/s10681-019-2335-3.

Felix, L.P. and M. Guerra. 2010. Variation in chromosome number and the basic number of subfamily Epidendroideae (Orchidaceae). Bot. J. Linn. Soc. 163:234-278, https://doi.org/10.1111/ j.1095-8339.2010.01059.x.

Flavell, R.B., M.D. Bennett, J.B. Smith, and D.B. Smith. 1974. Genome size and the proportion of repeated nucleotide sequence DNA in plants. Biochem. Genet. 12:257-269, https://doi.org/ 10.1007/BF00485947.

Goldman, D., J. Freudenstein, P. Kores, M. Molvray, D. Jarrell, W. Whitten, K. Cameron, R. Jansen, and M. Chasei. 2001. Phylogenetics of Arethuseae (Orchidaceae) based on plastid matK and $r b c \mathrm{~L}$ sequences. Syst. Bot. 37:670-695, https:// doi.org/10.1043/0363-6445-26.3.670.

Grabiele, M., J.C. Cerutti, D.H. Hojsgaard, R.D. Almada, J.R. Davina, and A.I. Honfi. 2013. Comparative cytogenetics in Cyclopogon (Orchidaceae). Biologia 68:48-54, https://doi. org/10.2478/s11756-012-0127-5.

Greilhuber, J., J. Dolezel, M.A. Lysak, and M.D. Bennett. 2005. The origin, evolution and proposed stabilization of the terms "genome size" and "C-value" to describe nuclear DNA contents. Ann. Bot. 95:255-260, https://doi.org/ 10.1093/aob/mci019.

Guerra, M. 2012. Cytotaxonomy: The end of childhood. Plant Biosyst. 146:703-710, https://doi. org/10.1080/11263504.2012.717973.

Harlan, J.R. 1975. On Ö. Winge and a prayer: The origins of polyploidy. Bot. Rev. 41:361-390, https://doi.org/10.1007/BF02860830.

Jang, T.-s. and H. Weiss-schneeweiss. 2018. Chromosome numbers and polyploidy events in Korean non-commelinids monocots: A contribution to plant systematics. Korean J. Plant Taxon. 48:260-277, https://doi.org/ 10.11110/kjpt.2018.48.4.260.

Kohler, C., O.M. Scheid, and A. Erilova. 2010. The impact of the triploid block on the origin and evolution of polyploid plants. Trends Genet. 26:142-148, https://doi.org/10.1016/j. tig.2009.12.006.

Kovalsky, I.E., J.M.R. Luque, G. Elias, S.A. Fernandez, and V.G.S. Neffa. 2018. The role of triploids in the origin and evolution of polyploids of Turnera sidoides complex (Passifloraceae, Turneroideae). J. Plant Res. 131:77-89, https://doi.org/10.1007/s10265-017-0974-9.

Leitch, I.J., I.M. Kahandawala, J. Suda, L. Hanson, M.J. Ingrouille, M.W. Chase, and M.F. Fay. 2009. Genome size diversity in orchids: Consequences and evolution. Ann. Bot. 104:469-481, https://doi.org/10.1002/cbdv.200890076.

Levan, A., K. Fredga, and A.A. Sandberg. 1964. Nomenclature for centromeric position on chromosomes. Hereditas 52:201-220, https://doi. org/10.1111/j.1601-5223.1964.tb01953.x.

Levin, D.A. 2002. The role of chromosomal change in plant evolution. Oxford University Press, New York, NY.
Li, L., D.P. Ye, M. Niu, H.F. Yan, T.L. Wen, and S.J. Li. 2015. Thuniopsis: A new orchid genus and phylogeny of the tribe Arethuseae (Orchidaceae). PLoS One 10:e0132777, https:// doi.org/10.1371/journal.pone.0132777.

Li, X.L. and R.Y. Chen. 1987. Studies on chromosomes of Orchidaceae in China, p. 301-307. In: D. Hong (ed.). Plant Chromosome Research. Organizing Committee Sino-Japanese Symposium on Plant Chromosomes, Beijing.

Li, X.L., R.Y. Chen, and R. Tanaka. 1992. Reports on chromosome numbers of some orchids cultivated in China. La Kromosomo II:67-68.

Mandakova, T. and M.A. Lysak. 2018. Post-polyploid diploidization and diversification through dysploid changes. Curr. Opin. Plant Biol. 42:55-65, https:// doi.org/10.1016/j.pbi.2018.03.001.

Medeiros-Neto, E., F. Nollet, A.P. Moraes, and L.P. Felix. 2017. Intrachromosomal karyotype asymmetry in Orchidaceae. Genet. Mol. Biol. 40:610-619, https://doi.org/10.1590/1678-4685gmb-2016-0264.

Moraes, A.P., S. Koehler, J.S. Cabral, S.S.L. Gomes, L.F. Viccini, F. Barros, L.P. Felix, M. Guerra, and E.R. Forni-Martins. 2017. Karyotype diversity and genome size variation in Neotropical Maxillariinae orchids. Plant Biol. 19:298-308, https://doi.org/ 10.1111/plb. 12527.

Myo, M.M.T., A. Pal, and S. Jha. 2011. Chromosome number and modal karyotype in a polysomatic endangered orchid, Bulbophyllum auricomum Lindl., the Royal Flower of Myanmar. Plant Syst. Evol. 294:167-175, https://doi. org/10.1007/s00606-011-0459-6.

Oliveira, L.D.R., R.T. de Faria, C.D. Ruas, P.M. Ruas, M.D. Santos, and V.P. Carvalho. 2010. Genetic analysis of species in the genus Catasetum (Orchidaceae) using RAPD markers. Braz. Arch. Biol. Techn. 53:375-387, https://doi.org/ 10.1590/S1516-89132010000200017.

Pellicer, J., L.J. Kelly, I.J. Leitch, W.B. Zomlefer, and M.F. Fay. 2014. A universe of dwarfs and giants: Genome size and chromosome evolution in the monocot family Melanthiaceae. New Phytol. 201:1484-1497, https://doi.org/ 10.1111/nph.12617.

Peruzzi, L., I.J. Leitch, and K.F. Caparelli. 2009. Chromosome diversity and evolution in Liliaceae. Ann. Bot. 103:459-475, https://doi.org/ 10.1093/aob/mcn230.

Ramsey, J. and D.W. Schemske. 1998. Pathways, mechanisms, and rates of polyploid formation in flowering plants. Annu. Rev. Ecol. Syst. 29:467-501, https://doi.org/10.1146/annurev. ecolsys.29.1.467.

Shan, F.C., G.J. Yan, and J.A. Plummer. 2003. Karyotype evolution in the genus Boronia (Rutaceae). Bot. J. Linn. Soc. 142:309-320, https:// doi.org/10.1046/j.1095-8339.2003.00163.x.

Sharma, S.K. and Y. Mukai. 2015. Chromosome research in orchids: Current status and future prospects with special emphasis from molecular and epigenetic perspective. Nucleus 58:173-184, https://doi.org/10.1007/s13237-015-0152-1.

Stace, C.A. 2000. Cytology and cytogenetics as a fundamental taxonomic resource for the 20(th) and 21(st) centuries. Taxon 49:451-477, https:// doi.org/10.2307/1224344.

Stebbins, G.L. 1971. Chromosomal evolution in higher plants. Edward Arnold, London.
Tan, K.W. 1969. The systematic status of the genus Bletilla (Orchidaceae). Brittonia 21:202-214, https://doi.org/10.2307/2805572.

Tanaka, R. 1971. Types of resting nuclei in Orchidaceae. Bot. Mag. Tokyo 84:118-122, https:// doi.org/10.15281/jplantres1887.84.118.

Tanaka, R. and H. Kamemoto. 1984. Chromosomes in orchids: Counting and numbers, p. 325-397. In: Orchid biology: Reviews and perspectives. Comstock, Ithaca, NY.

Turco, A., A. Albano, P. Medagli, S. Pulvirenti, and S. D'Emerico. 2018. New cytological data in Ophrys sect. Pseudophrys Godfery and comparative karyomorphological studies in Ophrys L. (Orchidaceae). Plant Biosyst. 152:901-910, https://doi.org/10.1080/11263504.2017.1362058. van den Berg, C., D.H. Goldman, J.V. Freudenstein, A.M. Pridgeon, K.M. Cameron, and M.W. Chase. 2005. An overview of the phylogenetic relationships within Epidendroideae inferred from multiple DNA regions and recircumscription of Epidendreae and Arethuseae (Orchidaceae). Amer. J. Bot. 92:613-624, https://doi. org/10.3732/ajb.92.4.613.

Venora, G., S. Blangiforti, M.R. Castiglione, D. Pignone, F.P. Losavio, and R. Cremonini. 2002. Chromatin organisation and computer aided karyotyping of Triticum durum Desf. cv. Timilia. Caryologia 55:91-98, https://doi.org/ 10.1080/00087114.2002.10589262.

Wang, Y., H.M. Du, J. Zhang, T. Chen, Q. Chen, H.R. Tang, and X.R. Wang. 2018. Ploidy level of Chinese cherry (Cerasus pseudocerasus Lindl.) and comparative study on karyotypes with four Cerasus species. Scientia Hort. 232:46-51, https:// doi.org/10.1016/j.scienta.2017.12.065.

Yang, L.M., D.H. Koo, D.W. Li, T. Zhang, J.M. Jiang, F.S. Luan, S.S. Renner, E. Henaff, W. Sanseverino, J. Garcia-Mas, J. Casacuberta, D.A. Senalik, P.W. Simon, J.F. Chen, and Y.Q. Weng. 2014. Next-generation sequencing, FISH mapping and synteny-based modeling reveal mechanisms of decreasing dysploidy in Cucumis. Plant J. 77:16-30, https://doi.org/ 10.1111/tpj.12355.

Yeh, H.Y., C.S. Lin, H. de Jong, and S.B. Chang. 2017. Two reported cytotypes of the emergent orchid model species Erycina pusilla are two different species. Euphytica 213:1-10, https:// doi.org/10.1007/s10681-017-2026-x.

Zarco, C.R. 1986. A new method for estimating karyotype asymmetry. Taxon 35(3):526-530, https://doi.org/10.2307/1221906.

Zhang, L., B. Cao, and C. Bai. 2013. New reports of nuclear DNA content for 66 traditional Chinese medicinal plant taxa in China. Caryologia 66:375-383, https://doi.org/10.1080/00087114. 2013.859443.

Zhang, M., Q.S. Shao, E.T. Xu, Z.A. Wang, Z. Wang, and L.H. Yin. 2019. Bletilla striata: A review of seedling propagation and cultivation modes. Physiol. Mol. Biol. Plants 25:601-609, https://doi.org/10.1007/s12298-019-00644-w.

Zhou, D., W. Chang, B. Liu, G. Chen, Y. Yang, Y. Hao, Y. Hou, and N. Li. 2020. Stilbenes from the tubers of Bletilla striata with potential anti-neuroinflammatory activity. Bioorg. Chem. 97:103715, https://doi.org/ 10.1016/j.bioorg.2020.103715.

Zonneveld, B.J.M., I.J. Leitch, and M.D. Bennett. 2005. First nuclear DNA amounts in more than 300 angiosperms. Ann. Bot. 96:229-244, https://doi.org/10.1093/aob/mci170. 
Supplemental Table 1. Detailed location information and ploidy levels of the Bletilla plants collected from China.

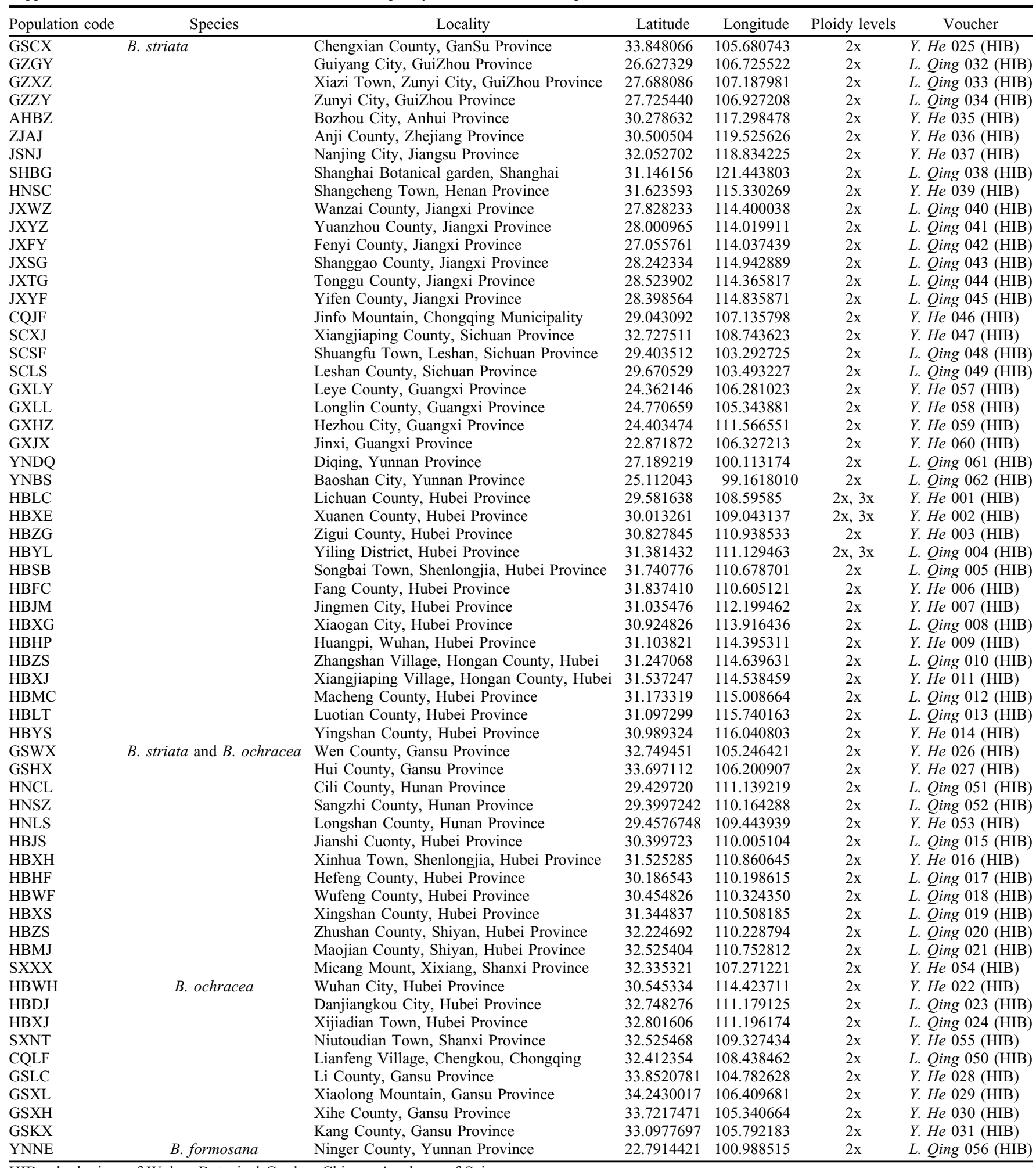

$\mathrm{HIB}=$ herbarium of Wuhan Botanical Garden, Chinese Academy of Sciences. 
Supplemental Table 2. A list of species sampled, vouchers and GenBank accession number. Markers noted \#\#\#\# are sequences not available.

\begin{tabular}{|c|c|c|c|c|}
\hline Species name & Vouchers & ITS & $\operatorname{mat} K$ & $\operatorname{trn} L$ \\
\hline B. striata (Thunb.) Rchb. f. -1 & Chase $\mathrm{O}-556(\mathrm{~K})$ & AF461466 & AF263630 & AF519939 \\
\hline B. ochracea Schltr. -1 & BS02MT02 & MH520969 & \#\#\#\# & \#\#\#\# \\
\hline B. sinensis (Rolfe) Schltr. -1 & BSMZ02 (NJNU) & KP866835 & \#\#\#\# & \#\#\#\# \\
\hline B. sinensis (Rolfe) Schltr. -2 & BSMZ03 (NJNU) & KP866836 & \#\#\#\# & \#\#\#\# \\
\hline B. formosana (Hayata) Schltr. -1 & AHBZ03 (NJNU) & KF698629 & \#\#\#\# & \#\#\#\# \\
\hline B. formosana (Hayata) Schltr. -2 & BFBZ01 (NJNU) & KP866832 & \#\#\#\# & \#\#\#\# \\
\hline
\end{tabular}

ITS = internal transcribed spacer. 